\title{
Effects of vitamin D and quercetin, alone and in combination, on cardiorespiratory fitness and muscle function in physically active male adults
}

This article was published in the following Dove Press journal:

Open Access Journal of Sports Medicine

24 July 2015

Number of times this article has been viewed

\author{
Shane D Scholten' \\ Igor N Sergeev ${ }^{2}$ \\ Qingming Song ${ }^{3}$ \\ Chad B Birger ${ }^{4}$
}

'Exercise and Sport Sciences, Augustana College, Sioux Falls, ${ }^{2}$ Department of Health and Nutritional Sciences, South Dakota State University, Brookings, SD, ${ }^{3}$ Gold Green Farm Corporation, Hammonton, NJ, ${ }^{4}$ Center for Health Outcomes and Prevention Research, Sanford Research, Sioux Falls, SD, USA

Correspondence: Shane D Scholten Exercise and Sport Sciences, Augustana College, 200I South Summit Avenue, Sioux Falls, SD 57197, USA

Tel +l 6052745469

Email shane.scholten@augie.edu
Introduction: Vitamin D and the antioxidant quercetin, are promising agents for improving physical performance because of their possible beneficial effects on muscular strength and cardiorespiratory fitness.

Purpose: The purpose of this study was to determine the effects of increased intakes of vitamin $\mathrm{D}$, quercetin, and their combination on antioxidant status, the steroid hormone regulators of muscle function, and measures of physical performance in apparently healthy male adults engaged in moderate-to-vigorous-intensity exercise training.

Methods: A total of 40 adult male participants were randomized to either 4,000 IU vitamin $\mathrm{D} / \mathrm{d}, 1,000 \mathrm{mg} / \mathrm{d}$ quercetin, vitamin D plus quercetin, or placebo for 8 weeks. Measures of cardiorespiratory fitness and muscle function, blood markers for antioxidant and vitamin D status, and hormones 1,25-dihydroxyvitamin $\mathrm{D}_{3}\left(1,25(\mathrm{OH})_{2} \mathrm{D}_{3}\right)$ and testosterone were measured pre- and postsupplementation.

Results: At enrollment, $88.6 \%$ of participants were vitamin D sufficient (serum 25-hydroxyvitamin D $>50 \mathrm{nmol} / \mathrm{L}$ ) and had normal serum testosterone levels. Supplementation with vitamin D significantly increased serum $25(\mathrm{OH}) \mathrm{D}$ concentration (by $87.3 \%$ in the vitamin D group, $P<0.001)$ and was associated with an increasing trend of testosterone concentration. There were no changes in concentration of $1,25(\mathrm{OH})_{2} \mathrm{D}_{3}$ and markers of antioxidant status associated with vitamin D or quercetin supplementation. No improvements in physical performance measures associated with vitamin D and quercetin supplementation were found.

Conclusion: The findings obtained demonstrate that long-term vitamin D and quercetin supplementation, alone or in combination, does not improve physical performance in male adults with adequate vitamin $\mathrm{D}$, testosterone, and antioxidant status.

Keywords: 25-hydroxyvitamin D, oxidative stress, physical performance, antioxidant status, testosterone

\section{Introduction}

Dietary supplementation in athletes is popular for the purposes of maintaining health and improving physical performance. ${ }^{1,2}$ Combining multiple supplements such as flavonoids and vitamins will affect multiple biological targets, offering advantages over treatments with a single product. This strategy is often used in an attempt to improve physical performance. ${ }^{3-7}$

Supplementation with antioxidants has been suggested to improve physical performance through reducing reactive oxygen species. ${ }^{8-11}$ Quercetin, a flavanol abundant in many commonly consumed fruits and vegetables, is one of the most potent antioxidants effective in reducing reactive oxygen species in vitro and in vivo. ${ }^{12-14}$ However, it remains unclear whether quercetin supplementation increases antioxidant status 
or reduces oxidative stress, leading to enhanced physical performance. ${ }^{4,15-18}$

Interest in vitamin D supplementation has increased recently due to reports indicating that low cardiorespiratory fitness ${ }^{19-22}$ and impaired muscular strength ${ }^{23-26}$ in athletes are associated with low vitamin D status. A significant percentage $(57 \%-91 \%)$ of athletes are reported to have insufficient vitamin D status. ${ }^{27-29}$ Most commonly, vitamin D insufficiency is due to inadequate sun exposure and affects athletes who train indoors, train early morning or late evening hours, live in far northern or far southern latitudes, or have dark skin. ${ }^{30}$

Vitamin $\mathrm{D}_{3}$ is a precursor to a steroid hormone, 1,25dihydroxyvitamin $\mathrm{D}_{3}\left(1,25(\mathrm{OH})_{2} \mathrm{D}_{3}\right){ }^{26,31-33}$ Vitamin D receptors are located in numerous types of cells within the body, including those of skeletal and cardiac muscle, endothelium, and the nervous system..$^{26,31,33,34}$ In addition, vitamin D receptors are expressed in the male reproductive system and appear to influence the production of testosterone, ${ }^{35,36}$ which can improve muscular strength. ${ }^{37}$ The hormone $1,25(\mathrm{OH})_{2} \mathrm{D}_{3}$ also functions (as other steroid hormones) via nongenomic mechanisms, including the mechanisms converging on cellular $\mathrm{Ca}^{2+}$ signaling. ${ }^{26,38-41}$

Low vitamin D status may affect skeletal and cardiac muscle because it is associated with decreased amino acid uptake, prolonged time to peak muscle contraction and relaxation, dysregulation of intracellular $\mathrm{Ca}^{2+}$, muscle weakness, myalgia, impaired neuromuscular function, and hypotonia. ${ }^{42,43}$ Supplementation with vitamin $\mathrm{D}$ has the potential to improve physical performance through its role in regulation of $\mathrm{Ca}^{2+}$ signaling in the muscle as well as biosynthesis of the muscle contractile proteins. ${ }^{33,39,44,45}$ Several authors studied the association of vitamin D status with physical performance, but results were inconclusive. ${ }^{46-49}$ It is interesting to note that, similar to quercetin, vitamin $\mathrm{D}$ has been shown to reduce oxidative stress. ${ }^{50}$ Moreover, vitamin D has anti-inflammatory properties ${ }^{51}$ and vitamin $\mathrm{D}$ status was observed to be inversely associated with inflammation in runners. ${ }^{52}$

It is possible that supplementation with vitamin D and quercetin could improve physical performance through the direct and indirect effects in reducing oxidative stress and increasing production of hormones - testosterone and $1,25(\mathrm{OH})_{2} \mathrm{D}_{3}$ - involved in regulation of muscle function; the combined supplementation could be more effective because it will target multiple pathways for improving muscle functioning.

This study was undertaken to determine whether dietary supplementation with vitamin $\mathrm{D}_{3}$ and quercetin, alone or in combination, improves physical performance in male adults. We hypothesized that vitamin $\mathrm{D}_{3}$ and quercetin supplementation will increase the steroid hormone regulators of muscle function (testosterone, $1,25(\mathrm{OH})_{2} \mathrm{D}_{3}$ ), improve antioxidant status, and reduce oxidative stress, resulting in improved physical performance. The results obtained do not support these hypotheses: supplementation with vitamin D and quercetin did not influence steroid hormone regulators of muscle function and antioxidant status, resulting in no improvements in physical performance.

\section{Materials and methods \\ Participants}

A total of 40 physically active males volunteered to participate after preliminary screening and explanation of all procedures. Written informed consent was obtained from all participants in accordance to the experimental procedures approved by the University of South Dakota (Institutional Review Board [IRB] Protocol number: 2012.098), South Dakota State University (IRB Protocol number: IRB1205004-EXP), and University of Sioux Falls (IRB Protocol number: E-02) Institutional Review Boards. Following consent, all volunteers completed a medical history, an exercise history, and a Physical Activity Readiness Questionnaires (PAR-Q). Volunteers were included if they met American College of Sports Medicine's (ACSM's) standards for fitness (moderate to vigorous physical exercise 3-5 days per week for 30-90 $\mathrm{min} / \mathrm{d}$ ), exercised primarily indoors, and were males between the age of 25 and 45 . Volunteers were excluded if they used indoor tanning and had two or more of the following ACSM risk factors: family history of heart disease, cigarette smoking, hypertension, dyslipidemia, impaired fasting glucose, obesity, or sedentary lifestyle. Other exclusions included supplementation with vitamin D, quercetin, testosterone, and prescription medications, such as anticoagulants or antibiotics.

The participants were instructed to maintain their current training program and not alter the frequency, intensity, duration, or mode of exercise during the study. Participants were also instructed to maintain their dietary habits, record 24-hour diet analysis pretesting to consume the same foods posttesting, and refrain from any supplementation. Study personnel contacted participants weekly to record physical activity and to monitor adherence.

Participants were randomly assigned in a doubleblind manner to the vitamin $\mathrm{D}_{3}(4,000 \mathrm{IU} / \mathrm{d})$, quercetin $(1,000 \mathrm{mg} / \mathrm{d})$, vitamin $\mathrm{D}_{3}$ plus quercetin $(4,000 \mathrm{IU} / \mathrm{d}$ plus $1,000 \mathrm{mg} / \mathrm{d}$, respectively), or placebo groups. The 
"plotblockrand" function in R 3.0.2 was used to create the randomization cards used when assigning participants to the groups. Treatment started after the completion of the fourth laboratory visit and continued for 8 weeks (Figure 1).

\section{Supplementation}

The quercetin supplement contained 1,000 mg of quercetin (PureBulk, Roseburg, OR, USA). This amount was based on the previous research regarding safety, bioavailability, and human plasma quercetin concentrations achieved with supplementation. ${ }^{15}$ The vitamin D supplement (PureBulk) contained 4,000 IU of vitamin $\mathrm{D}_{3}$ (cholecalciferol), which is the recommended tolerable upper intake level (UL) for this vitamin. ${ }^{53}$ The supplier provided certificates of analysis for quercetin and vitamin $\mathrm{D}_{3}$. The supplements were also tested and certified by an independent laboratory (Novatia, Monmouth Junction, NJ, USA) (quercetin, 96.7\%; vitamin $\mathrm{D}_{3}$, $94.3 \%$ by liquid chromatography/mass spectroscopy). Microcrystalline cellulose (Professional Compunding Centers of America, Houston, TX, USA) was used as a placebo. All supplements were in powder form, dyed for identical color, and packaged in visually identical capsules and containers (Pharmacy Specialties, Sioux Falls, SD, USA).

40 subjects were enrolled after eligibility assessment

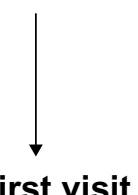

- Blood drawn

- LT and $\mathrm{VO}_{2 \text { max }}$ assessments

- $5 \mathrm{~km}$ TT familiarization

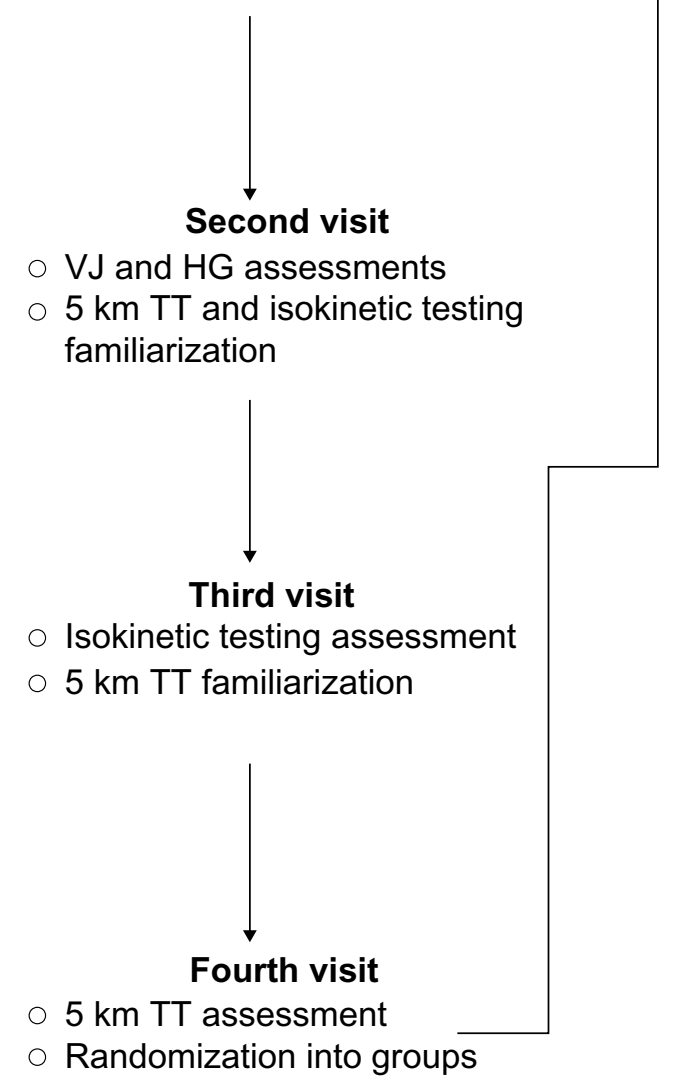

8 weeks supplementation

- Weekly communication to ensure subjects maintained current exercise volume and consumed supplements

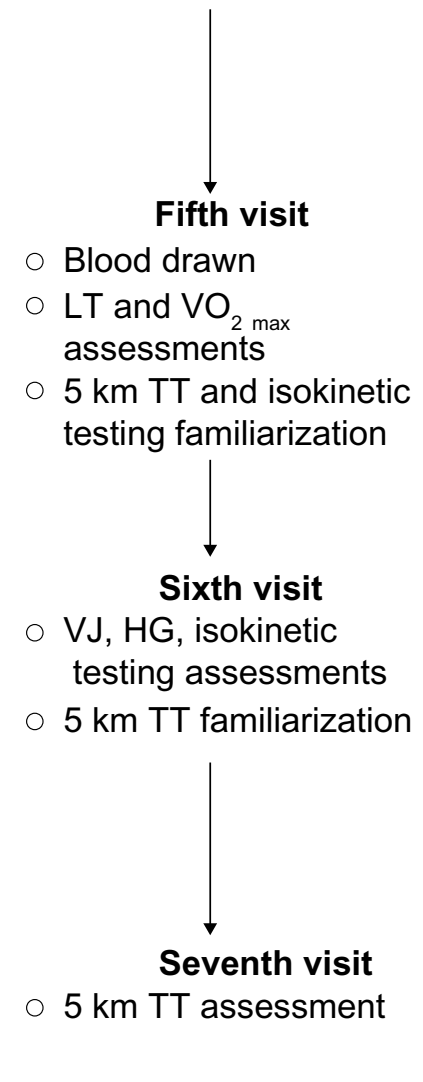

Figure I Methods schematic.

Notes: The time between visits was at least 24 hours to allow for recovery. Participants completed testing in seven total visits, with 8 weeks of supplementation separating the pre- and posttesting period.

Abbreviations: LT, lactate threshold; $\mathrm{VO}_{2 \max }$, maximal oxygen consumption; $5 \mathrm{~km}$ TT, $5 \mathrm{~km}$ time trial; VJ, vertical jump; HG, hand grip strength. 


\section{Cardiorespiratory fitness} $\mathrm{VO}_{2 \text { max }}$

$\mathrm{VO}_{2 \max }$ (maximal oxygen consumption) (aerobic capacity) was determined for all the participants using a previously published graded protoco ${ }^{54}$ on a motorized treadmill (TrackMaster Model TMX325C), with expired gases analyzed using a MedGraphics CPX/D automated metabolic cart (St Paul, MN, USA).

\section{Lactate threshold}

After a 5-minute warm-up, the initial treadmill speed was set according to the participant's fitness and increased by $1 \mathrm{~km} / \mathrm{h}$, between each of the 3-minute successive stages. Each stage was separated by a 30 -second period of rest, during which a fingertip capillary blood sample was collected and analyzed using a Lactate Pro blood lactate test meter (Arkray Inc., Kyoto, Japan). Lactate threshold (LT) was defined using the running speed at which an abrupt increase in blood lactate occurred..$^{55}$

\section{$5 \mathrm{~km}$ time trial}

Participants were habituated with the $5 \mathrm{~km}$ time trial $(5 \mathrm{~km}$ TT) by including three familiarization sessions prior to the test performance. The $5 \mathrm{~km}$ TT was performed in an airconditioned laboratory (temperature: $18.0^{\circ} \mathrm{C} \pm 1.2^{\circ} \mathrm{C}$ ) using a TrackMaster treadmill, with a fan positioned $1 \mathrm{~m}$ in front of the subject to provide cooling. Participants started with a 5-minute warm-up followed by stretching. Before the $5 \mathrm{~km} \mathrm{TT}$, participants were instructed to complete the $5 \mathrm{~km} \mathrm{TT}$ in the least amount of time as possible (ie, to race the $5 \mathrm{~km} \mathrm{TT}$ ). During the $5 \mathrm{~km} \mathrm{TT}$, participants were allowed to adjust the treadmill speed as desired. Participants were given feedback with respect to distance and time elapsed, but were not allowed to know their running speed. Participants were informed of their final $5 \mathrm{~km}$ TT time at completion. Water consumption was encouraged and allowed ad libitum. Exercise heart rates were measured using a wireless transmitter system (Polar Electro Inc., Woodbury, NY, USA).

\section{Muscle function}

\section{Hand grip strength}

The JAMAR hand dynamometer (Lafayette Instrument, Lafayette, IN, USA) was used to measure grip strength. The test was performed with the subject in a seated position using the dominant hand, with the shoulder adducted, elbow flexed at $90^{\circ}$, and a neutral wrist position. Participants were instructed to squeeze as hard as possible. This was repeated three times with a 60 -second rest between each repetition. The mean value of the repeated measures was reported.

\section{Vertical jump}

Vertical jump (VJ) height was assessed using the VERTEC (Questtek Corp, Northridge, CA, USA). The height of the VERTEC was adjusted in accordance with the manufacturer's guidelines. Participants were given three attempts to reach their maximum height using counter movement jump. The highest of the three trials was recorded.

\section{Isokinetic leg strength}

Isokinetic knee extension (IKE) and isokinetic knee flexion (IKF) of the dominant limb were determined using a computerized dynamometer in an isokinetic mode (Biodex Multi-joint System 3, Shirley, NY, USA), using a previously published protocol. ${ }^{56}$ Following warm-up, participants performed five repetitions of knee flexion and extension at angular velocities of $60 \% \mathrm{~s}, 120 \% \mathrm{~s}$, and $300 \% \mathrm{~s}$, with a 3-minute rest between each set. Corrections were made for gravity. ${ }^{56}$ Participants were given one familiarization session 24-48 hours before testing. The maximum torque produced in a single repetition was used as the measure of strength.

\section{Markers of antioxidant, vitamin D, and testosterone status}

Blood samples were drawn into tubes with no additives, serum was aliquoted, immediately frozen, and stored at $-80^{\circ} \mathrm{C}$ until analysis. The following kits were used: 25-hydroxyvitamin D ELISA (enzyme-linked immunosorbent assay) (Immunodiagnostics Systems, Scottsdale, AZ, USA), $1,25(\mathrm{OH})_{2}$ D ELISA (Immunodiagnostics Systems), testosterone ELISA (ALPCO Immunoassays, Salem, NH, USA), Total Antioxidant Capacity Assay, OxiSelect Superoxide Dismutase Activity Assay, OxiSelect MDA Adduct ELISA, OxiSelect Protein Carbonyl ELISA (Cell Biolabs, Inc., San Diego, CA, USA). The kits for measuring vitamin D metabolites employ highly specific $25(\mathrm{OH}) \mathrm{D}$ and $1,25(\mathrm{OH})_{2} \mathrm{D}_{3}$ antibodies. Solid-phase monoclonal anti-1,25(OH) ${ }_{2} \mathrm{D}_{3}$ was used for immunoextraction of $1,25(\mathrm{OH})_{2} \mathrm{D}_{3}$ prior to detection of the hormone by ELISA.

\section{Statistical analysis}

The participants were randomized into four groups: vitamin $\mathrm{D}_{3}(\mathrm{D}, \mathrm{n}=14)$, quercetin $(\mathrm{Q}, \mathrm{n}=6)$, vitamin $\mathrm{D}_{3}$ plus quercetin $(\mathrm{D}+\mathrm{Q}, \mathrm{n}=6)$, and placebo $(\mathrm{P}, \mathrm{n}=14)$. A multiple ANOVA with interactions was used to compare differences between supplementation groups. A Tukey post hoc test was run for 
significant tests. Significance for all comparisons was set at $P<0.05$. This data analysis allowed group comparisons for individual assays and performance measures. All data were analyzed using $\mathrm{R}$ version 3.0.2.

\section{Results}

\section{Subject description and assessment}

Around 40 participants were recruited for the study during winter of 2013 (January-February), with follow-up occurring 8 weeks after enrollment. One of these participants was excluded because of not meeting training requirements during the 8-week time period. Following analysis of presupplementation data, four participants (three from the D group, one from the $\mathrm{P}$ group) were removed from statistical analysis as outliers because of high serum testosterone concentrations (defined as significantly outside the normal range of 4.5-28.0 nmol/L; the values were confirmed as outliers using interquartile range [IQR] test, $\mathrm{R}$ 3.0.2). Statistical analysis was performed with and without the participants with high testosterone level. The exclusion of these participants did not change the significance or nonsignificance of results for any parameter. Final statistical analysis was completed using 35 participants $(\mathrm{P}, \mathrm{n}=12 ; \mathrm{D}$, $\mathrm{n}=11 ; \mathrm{Q}, \mathrm{n}=6 ; \mathrm{Q}+\mathrm{D}, \mathrm{n}=6)$. Upon enrollment, 31/35 (88.6\%) had $25(\mathrm{OH}) \mathrm{D}$ concentration $>50 \mathrm{nmol} / \mathrm{L}$ and $9 / 35(25.7 \%)$ had $25(\mathrm{OH}) \mathrm{D}$ concentration $>75 \mathrm{nmol} / \mathrm{L}$. The serum $25(\mathrm{OH}) \mathrm{D}$ concentration increased by $58.7 \pm 30.5 \mathrm{nmol} / \mathrm{L}$ in the $\mathrm{D}$ group and by $31.0 \pm 14.0 \mathrm{nmol} / \mathrm{L}$ in the $\mathrm{D}+\mathrm{Q}$ group at the end of supplementation period (4,000 IU/d of vitamin $\mathrm{D}_{3}$ for 8 weeks). Descriptive statistics of the participants are presented in Table 1. The age, height, and weight of the participants ranged from 25 to 42 years, 172.7 to $193.0 \mathrm{~cm}$, and 65.9 to $108.2 \mathrm{~kg}$, respectively. At the completion of the study, ethnic groups were $97 \%$ white and $3 \%$ black, which is similar to the local population demographics. Data collection was performed in Sioux Falls, SD, USA (latitude: $43.5^{\circ} \mathrm{N}$ ).

Table I Subject characteristics

\begin{tabular}{llllll}
\hline Group & $\begin{array}{l}\text { Age } \\
(\mathbf{y r})\end{array}$ & $\begin{array}{l}\text { Height } \\
\mathbf{( m )}\end{array}$ & $\begin{array}{l}\text { BW } \\
\mathbf{( k g )}\end{array}$ & $\begin{array}{l}\text { BMI } \\
\left(\mathbf{k g} / \mathbf{m}^{2}\right)\end{array}$ & $\begin{array}{l}\text { Physical } \\
\text { activity (h/d) }\end{array}$ \\
\hline Placebo & $29.9 \pm 1.5$ & $1.85 \pm 0.05$ & $90.0 \pm 4.7$ & $26.2 \pm 4.5$ & $4.1 \pm 0.4$ \\
Vitamin D & $32.8 \pm 1.7$ & $1.83 \pm 0.12$ & $78.8 \pm 2.3$ & $23.4 \pm 1.8$ & $4.5 \pm 1.8$ \\
Quercetin & $30.3 \pm 1.4$ & $1.87 \pm 0.08$ & $90.9 \pm 8.4$ & $25.9 \pm 1.9$ & $3.3 \pm 0.6$ \\
Vitamin D + & $32.2 \pm 3.7$ & $1.82 \pm 0.08$ & $76.1 \pm 5.7$ & $23.1 \pm 3.2$ & $4.0 \pm 0.5$ \\
quercetin & & & & & \\
\hline
\end{tabular}

Notes: There were no significant differences $(P<0.05)$ between groups for any variables. Values are mean \pm SEM.

Abbreviations: BW, body weight; BMI, body mass index; SEM, standard error of mean; yr, year; h/d, hour/day.

\section{Cardiorespiratory fitness and muscle function}

Physical performance outcomes are presented in Tables 2 and 3. The treatment groups were well-matched at the baseline for all outcome measures except $\mathrm{VO}_{2 \max }$ (the $\mathrm{Q}$ group had somewhat lower average $\mathrm{VO}_{2 \max }$ values, but there were no significant changes of $\mathrm{VO}_{2 \text { max }}$ in this group from pre- to postsupplementation). There were no significant changes in physical performance measures (VJ, HG [hand grip strength], IKF, IKE, $\mathrm{VO}_{2 \max }, 5 \mathrm{~km} \mathrm{TT}$, and LT) between any groups from pre- to postsupplementation. Isokinetic muscular performance outcomes are presented in Table 2. At baseline, the vitamin D group tended to have smaller torque values than other groups, but this difference was not statistically significant for any rotational joint speed. As expected, torque values decreased with increasing knee flexion and extension velocities.

\section{Markers of antioxidant, vitamin D, and testosterone status}

Figures 2 and 3 show serum markers of the vitamin D, testosterone, and antioxidant status before and after supplementation with vitamin $\mathrm{D}_{3}$ and quercetin. At baseline, no statistically significant differences in the vitamin D status (serum 25(OH)D concentration) and the steroid hormone regulators of muscle function (serum testosterone and $\left.1,25(\mathrm{OH})_{2} \mathrm{D}_{3}\right)$ were detected between the groups. As expected, supplementation with vitamin $\mathrm{D}_{3}$ resulted in a significant increase in serum $25(\mathrm{OH}) \mathrm{D}$ concentration in the D (by $87.3 \%, P<0.001$ ) and $\mathrm{D}+\mathrm{Q}$ groups (by $35.5 \%$, $P=0.045)$ (Figure 2A). It is important to note that an increase in $25(\mathrm{OH}) \mathrm{D}$ in the $\mathrm{D}$ and $\mathrm{D}+\mathrm{Q}$ groups was not accompanied by significant increases in physical performance (as measured by VJ, HG, IKF, IKE, $\mathrm{VO}_{2 \max }, 5 \mathrm{~km} \mathrm{TT}$, and LT). The concentration of the hormonal form of vitamin D, $1,25(\mathrm{OH})_{2} \mathrm{D}$, remained within the narrow normal physiological range in all groups (Figure 2B).

There were no statistically significant changes in the testosterone concentration from pre- to postsupplementation (Figure 2C). Specifically, the testosterone concentration was higher by $3.7 \%$ in the $\mathrm{P}$ group $(P=0.834), 41.2 \%$ in the D group $(P=0.216), 0 \%$ in the $\mathrm{Q}$ group $(P=0.998)$, and $3.4 \%$ in the $\mathrm{D}+\mathrm{Q}$ group $(P=0.849)$. These findings imply a strong increasing trend of testosterone concentration associated with vitamin $\mathrm{D}_{3}$ supplementation in participants with the normal initial testosterone levels. When participants with abnormally high baseline testosterone levels were included in statistical analysis, there was only $1.7 \%$ increase in the D group 
Table 2 The muscle performance outcomes

\begin{tabular}{|c|c|c|c|}
\hline & Presupplementation & Postsupplementation & $P$-value \\
\hline \multicolumn{4}{|c|}{ Knee flexion $60 \%$ s (Nm) } \\
\hline Placebo & $119.98 \pm 8.93$ & $|20.30 \pm 8.0|$ & 0.948 \\
\hline Vitamin D & $103.08 \pm 6.85$ & $107.26 \pm 5.15$ & 0.632 \\
\hline Quercetin & $117.96 \pm 12.65$ & $114.74 \pm 13.06$ & 0.863 \\
\hline $\begin{array}{l}\text { Vitamin D + } \\
\text { quercetin }\end{array}$ & $109.73 \pm 11.35$ & $117.73 \pm 9.53$ & 0.601 \\
\hline \multicolumn{4}{|c|}{ Knee extension $60 \% \mathrm{~s}(\mathrm{Nm})$} \\
\hline Placebo & $213.53 \pm 18.02$ & $209.58 \pm 22.15$ & 0.901 \\
\hline Vitamin D & $204.78 \pm 14.66$ & $209.4 I \pm 13.6 I$ & 0.786 \\
\hline Quercetin & $241.51 \pm 28.98$ & $239.13 \pm 30.22$ & 0.956 \\
\hline $\begin{array}{l}\text { Vitamin D + } \\
\text { quercetin }\end{array}$ & $213.34 \pm 25.22$ & $231.84 \pm 22.19$ & 0.594 \\
\hline \multicolumn{4}{|c|}{ Knee flexion $120 \%$ s (Nm) } \\
\hline Placebo & $100.13 \pm 7.27$ & $103.65 \pm 7.67$ & 0.732 \\
\hline Vitamin D & $96.49 \pm 4.85$ & $98.36 \pm 4.26$ & 0.789 \\
\hline Quercetin & $105.59 \pm 11.27$ & $104.51 \pm 10.78$ & 0.946 \\
\hline $\begin{array}{l}\text { Vitamin D + } \\
\text { quercetin }\end{array}$ & $106.77 \pm 11.14$ & $108.02 \pm 10.17$ & 0.936 \\
\hline \multicolumn{4}{|c|}{ Knee extension $120 \% / \mathrm{s}(\mathrm{Nm})$} \\
\hline Placebo & $193.04 \pm 14.10$ & $195.96 \pm 14.79$ & 0.829 \\
\hline Vitamin D & $173.61 \pm 11.23$ & $180.97 \pm 10.36$ & 0.623 \\
\hline Quercetin & $200.59 \pm 20.68$ & $211.23 \pm 25.75$ & 0.754 \\
\hline $\begin{array}{l}\text { Vitamin D + } \\
\text { quercetin }\end{array}$ & $199.60 \pm 21.16$ & $208.57 \pm \mid 8.81$ & 0.758 \\
\hline \multicolumn{4}{|c|}{ Knee flexion $300 \%$ s (Nm) } \\
\hline Placebo & $75.38 \pm 5.78$ & $79.74 \pm 5.54$ & 0.584 \\
\hline Vitamin D & $70.73 \pm 3.89$ & $73.46 \pm 3.86$ & 0.704 \\
\hline Quercetin & $72.77 \pm 6.22$ & $80.29 \pm 6.58$ & 0.425 \\
\hline $\begin{array}{l}\text { Vitamin D + } \\
\text { quercetin }\end{array}$ & $81.62 \pm 8.12$ & $81.34 \pm 8.34$ & 0.982 \\
\hline \multicolumn{4}{|c|}{ Knee extension $300 \%$ s (Nm) } \\
\hline Placebo & $129.11 \pm 7.90$ & $131.96 \pm 8.23$ & 0.748 \\
\hline Vitamin D & $119.51 \pm 6.95$ & $123.59 \pm 6.49$ & 0.598 \\
\hline Quercetin & $|38.67 \pm| 4.33$ & $142.88 \pm 15.90$ & 0.848 \\
\hline $\begin{array}{l}\text { Vitamin D + } \\
\text { quercetin }\end{array}$ & $136.69 \pm 12.72$ & $138.97 \pm 9.98$ & 0.890 \\
\hline \multicolumn{4}{|c|}{ Vertical jump (cm) } \\
\hline Placebo & $54.29 \pm 2.96$ & $56.09 \pm 2.81$ & 0.668 \\
\hline Vitamin D & $52.76 \pm 2.05$ & $54.38 \pm 1.90$ & 0.631 \\
\hline Quercetin & $56.52 \pm 3.92$ & $56.52 \pm 4.05$ & 0.999 \\
\hline $\begin{array}{l}\text { Vitamin D + } \\
\text { quercetin }\end{array}$ & $67.3 I \pm 5.58$ & $72.14 \pm 6.37$ & $0.58 \mathrm{I}$ \\
\hline \multicolumn{4}{|c|}{ Hand grip strength (N) } \\
\hline Placebo & $506.3 \pm 29.1$ & $534.1 \pm 28.7$ & 0.477 \\
\hline Vitamin D & $516.6 \pm 18.9$ & $516.6 \pm 15.3$ & $0.84 I$ \\
\hline Quercetin & $589.2 \pm 63.8$ & $590.0 \pm 53.3$ & 0.992 \\
\hline $\begin{array}{l}\text { Vitamin D + } \\
\text { quercetin }\end{array}$ & $547.5 \pm 54.9$ & $580.6 \pm 43.5$ & 0.658 \\
\hline
\end{tabular}

Notes: The duration of the supplementation period was 8 weeks. Concentric isokinetic knee flexion and extension were tested at $60 \% \mathrm{~s}, 180 \% \mathrm{~s}$, and $300 \% \mathrm{~s}$. There were no significant changes $(P<0.05)$ between any variable from pre- to postsupplementation. Values are mean \pm SEM.

Abbreviation: SEM, standard error of mean.

( $P=0.963), 2.5 \%$ in the $\mathrm{P}$ group $(P=0.949), 0 \%$ in the $\mathrm{Q}$ group ( $P=0.998)$, and $3.4 \%$ in the $\mathrm{D}+\mathrm{Q}$ group $(P=0.849)$.

The evaluation of antioxidant staus revealed significant variations in total antioxidant capacity (TAC) in serum, including a decrease in TAC values for all the treatment
Table 3 The cardiorespiratory performance outcomes

\begin{tabular}{|c|c|c|c|}
\hline & Presupplementation & Postsupplementation & $P$-value \\
\hline \multicolumn{4}{|c|}{$\mathrm{VO}_{2 \max }(\mathrm{mL} /(\mathbf{k g} \cdot \mathrm{min}))$} \\
\hline Placebo & $50.21 \pm 2.56$ & $49.92 \pm 2.27$ & 0.943 \\
\hline Vitamin D & $56.46 \pm 2.93$ & $55.77 \pm 2.66$ & 0.849 \\
\hline Quercetin & $43.56 \pm 1.65$ & $42.70 \pm 1.79$ & 0.733 \\
\hline $\begin{array}{l}\text { Vitamin D + } \\
\text { quercetin }\end{array}$ & $50.45 \pm 1.71$ & $51.97 \pm 1.96$ & 0.572 \\
\hline \multicolumn{4}{|c|}{$5 \mathrm{~km}$ time trial (minute) } \\
\hline Placebo & $27.25 \pm 1.32$ & $26.46 \pm 1.29$ & 0.711 \\
\hline Vitamin D & $23.7 I \pm I .50$ & $23.32 \pm 1.46$ & 0.809 \\
\hline Quercetin & $28.82 \pm 2.52$ & $28.74 \pm 2.40$ & 0.983 \\
\hline $\begin{array}{l}\text { Vitamin D + } \\
\text { quercetin }\end{array}$ & $26.28 \pm 1.98$ & $25.87 \pm 2.32$ & 0.895 \\
\hline \multicolumn{4}{|c|}{ Lactate threshold $(\mathrm{km} / \mathrm{h})$} \\
\hline Placebo & $10.70 \pm 0.45$ & $11.15 \pm 0.34$ & 0.512 \\
\hline Vitamin D & $12.02 \pm 0.72$ & $12.28 \pm 0.73$ & 0.550 \\
\hline Quercetin & $10.06 \pm 0.77$ & $10.14 \pm 0.82$ & 0.945 \\
\hline $\begin{array}{l}\text { Vitamin D + } \\
\text { quercetin }\end{array}$ & $10.68 \pm 0.46$ & $11.15 \pm 0.52$ & 0.513 \\
\hline
\end{tabular}

Notes: There were no significant changes $(P<0.05)$ between any variable from preto postsupplementation. There was a significant difference at presupplementation for $\mathrm{VO}_{2 \text { max }}$ between the $\mathrm{Q}$ and $\mathrm{P}$ groups $(P=0.034)$; however, there was no significant change in $\mathrm{VO}_{2 \text { max }}$ from pre- to postsupplementation in the $\mathrm{Q}$ and $\mathrm{P}$ groups. Values are mean \pm SEM.

Abbreviations: $\mathrm{VO}_{2 \text { max }}$, maximal oxygen consumption; SEM, standard error of mean; $Q$, quercetin; $P$, placebo.

groups and the placebo group from pre- to postsupplementation (Figure 3A). This may indicate that a relatively intensive long-term training program depletes antioxidant capacity and that the quercetin and vitamin D supplementations are not effective in preventing this decrease in TAC. The superoxide dismutase (SOD) activity in serum, which can serve as a marker of oxidative stress by indicating a release of the enzyme from the damaged tissues, ${ }^{57}$ was increased in the $\mathrm{P}$ group at the end of the evaluation period (Figure 3B). The combined vitamin $\mathrm{D}_{3}$ plus quercetin supplementation (the $\mathrm{D}+\mathrm{Q}$ group) resulted in a dramatic decrease $(71.7 \%, P<0.001)$ of serum SOD, possibly implying a protective antioxidant effect of the supplementation. No significant differences in lipid peroxidation (MDA [malondialdehyde]) and protein oxidation (protein carbonyl) were found between groups (Figure 3C and D), although a trend to the normalization (decrease) of postsupplementation MDA values and a significant decrease of the protein carbonyl postsupplementation values (by $19.3 \%, P=0.023$ ) were observed in the $\mathrm{D}+\mathrm{Q}$ group. Taken together, these findings imply that supplementation with vitamin $\mathrm{D}_{3}$ plus quercetin can be moderately effective in reducing chronic oxidative stress associated with a high level of long-term physical activity. However, no significant changes in physical performance between groups that can be associated with vitamin $\mathrm{D}_{3}$ and quercetin supplementation were observed. 


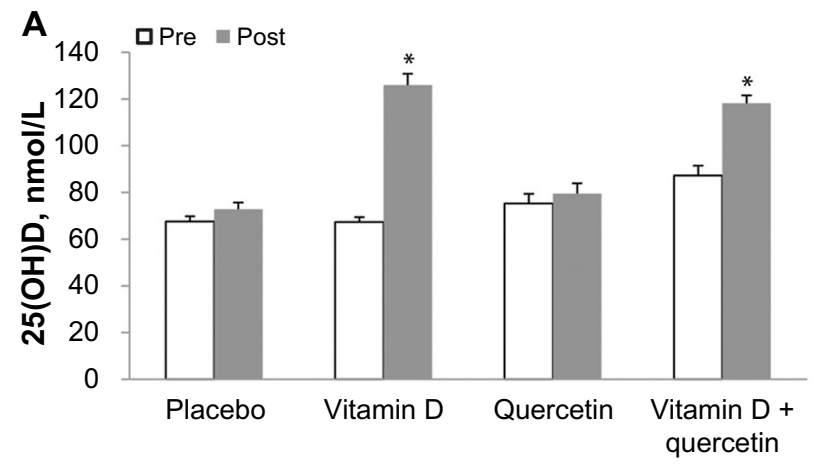

B
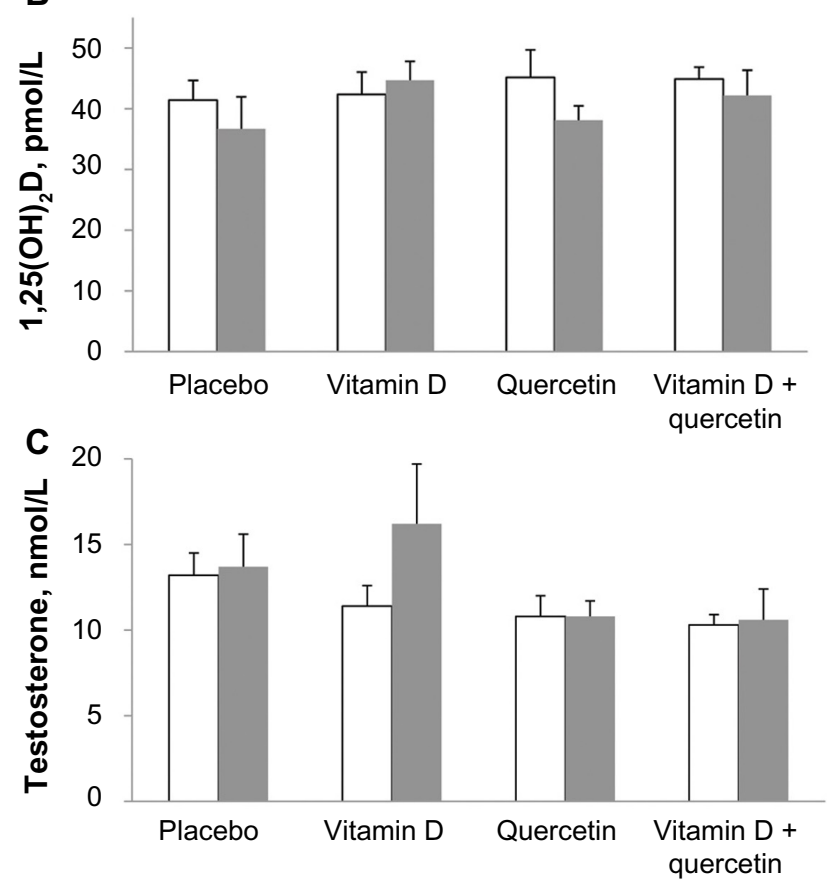

Figure 2 Concentrations of $25(\mathrm{OH}) \mathrm{D}, \mathrm{I}, 25(\mathrm{OH})_{2} \mathrm{D}$, and testosterone in serum. Notes: (A) Vitamin $D_{3}$ supplementation significantly increased serum $25(\mathrm{OH}) \mathrm{D}$ concentration in the vitamin $D_{3}(P<0.00 I)$ and $D+Q(P=0.045)$ groups. (B) No pre- to postsupplementation changes in $1,25(\mathrm{OH})_{2} \mathrm{D}$ concentration were observed. (C) Testosterone concentration increased by $41.2 \%(P=0.216)$ with vitamin $D_{3}$ supplementation. Values are mean \pm SEM. The asterisk indicates significant difference from pre- to postsupplementation $(P<0.05)$.

Abbreviations: I, $25(\mathrm{OH})_{2} \mathrm{D}, \mathrm{I}, 25$-dihydroxyvitamin $\mathrm{D}$; $\mathrm{D}+\mathrm{Q}$, vitamin $\mathrm{D}+$ quercetin; SEM, standard error of mean.

\section{Discussion}

The aims of this study were to evaluate the effects of vitamin D and quercetin supplementation on the cardiorespiratory and muscular fitness outcomes and determine the possible mechanisms of these effects, converging on the steroid hormone regulators of muscle function and linked to maintaining antioxidant status. The main findings obtained demonstrate that long-term supplementation of physically active male adults with vitamin $\mathrm{D}_{3}$ alone, quercetin alone, or their combination does not increase physical performance and does not produce significant changes in markers associated with antioxidant status and hormones (testosterone, 1,25( $\mathrm{OH})_{2} \mathrm{D}_{3}$ ) involved in regulation of the muscle function.
The Institute of Medicine recommends serum 25(OH)D concentration $>50 \mathrm{nmol} / \mathrm{L}$ as adequate for bone and overall health in healthy adult individuals. ${ }^{58}$ Our findings indicate that 31 of $35(88.6 \%)$ physically active male adults were vitamin D sufficient $(25(\mathrm{OH}) \mathrm{D}>50 \mathrm{nmol} / \mathrm{L})$ during winter months at a northern latitude $\left(43.5^{\circ} \mathrm{N}\right)$. The Endocrine Society defines vitamin D sufficiency as serum $25(\mathrm{OH})$ D concentration $>75 \mathrm{nmol} / \mathrm{L} .{ }^{59}$ At this level, 9 of 35 (25.7\%) study participants had sufficient vitamin D status. Several earlier studies indicate a wide range ( $9 \%-43 \%)$ of vitamin D sufficient status (defined as $25(\mathrm{OH}) \mathrm{D}$ concentration $>50 \mathrm{nmol} / \mathrm{L}$ ) in athletes. ${ }^{27-29,60,61}$

Based on previous studies, we expected that vitamin $\mathrm{D}_{3}$ supplementation with 4,000 IU/d would increase serum $25(\mathrm{OH}) \mathrm{D}$ concentration by approximately $50 \mathrm{nmol} / \mathrm{L}$ and peak after 4-5 weeks of supplementation. ${ }^{62-64}$ This statistically significant increase was achieved in the vitamin $\mathrm{D}_{3}$ group but not in the vitamin $\mathrm{D}_{3}$ plus quercetin group, possibly implying an antagonistic effect of quercetin supplementation on vitamin D status. Sufficient vitamin D status and normal $1,25(\mathrm{OH})_{2} \mathrm{D}$ concentration at presupplementation may explain the failure of vitamin $\mathrm{D}_{3}$ supplementation to increase physical performance in this study. The circulating $1,25(\mathrm{OH})_{2} \mathrm{D}$ concentration is homeostatically regulated and is not decreased until $25(\mathrm{OH}) \mathrm{D}$ drops below $25 \mathrm{nmol} / \mathrm{L}$ or even significantly less ("undetectable"). ${ }^{31,45} 1,25(\mathrm{OH})_{2} \mathrm{D}$ concentration in all participants of this study was within the normal and narrow range of physiological values (approximately $40 \mathrm{pmol} / \mathrm{L}$ ).

Previous studies have shown a positive association between serum 25(OH)D and testosterone. ${ }^{36,65,66}$ We found a nonsignificant increase in testosterone level with an increase in serum 25(OH)D. Despite an increasing trend in testosterone levels with vitamin D supplementation, physical performance outcomes remained unchanged. A much larger increase in testosterone concentration may be necessary for improved physical performance ${ }^{67}$ Additionally, the healthy young males of this study responded to vitamin $\mathrm{D}_{3}$ supplementation with only limited increase in testosterone concentration, probably because they have already achieved a high testosterone status associated with an increased physical activity and a decreased body mass index ${ }^{68}$

The observed increase in serum 25(OH)D concentration was not accompanied by significant changes in muscular performance. These results are consistent with meta-analyses performed using older adults. ${ }^{46,47}$ Although an increase in proximal lower limb muscle strength with vitamin D supplementation in vitamin $\mathrm{D}$ deficient $(<25 \mathrm{nmol} / \mathrm{L})$ elderly participants was demonstrated in one study ${ }^{69}$ we did not find 

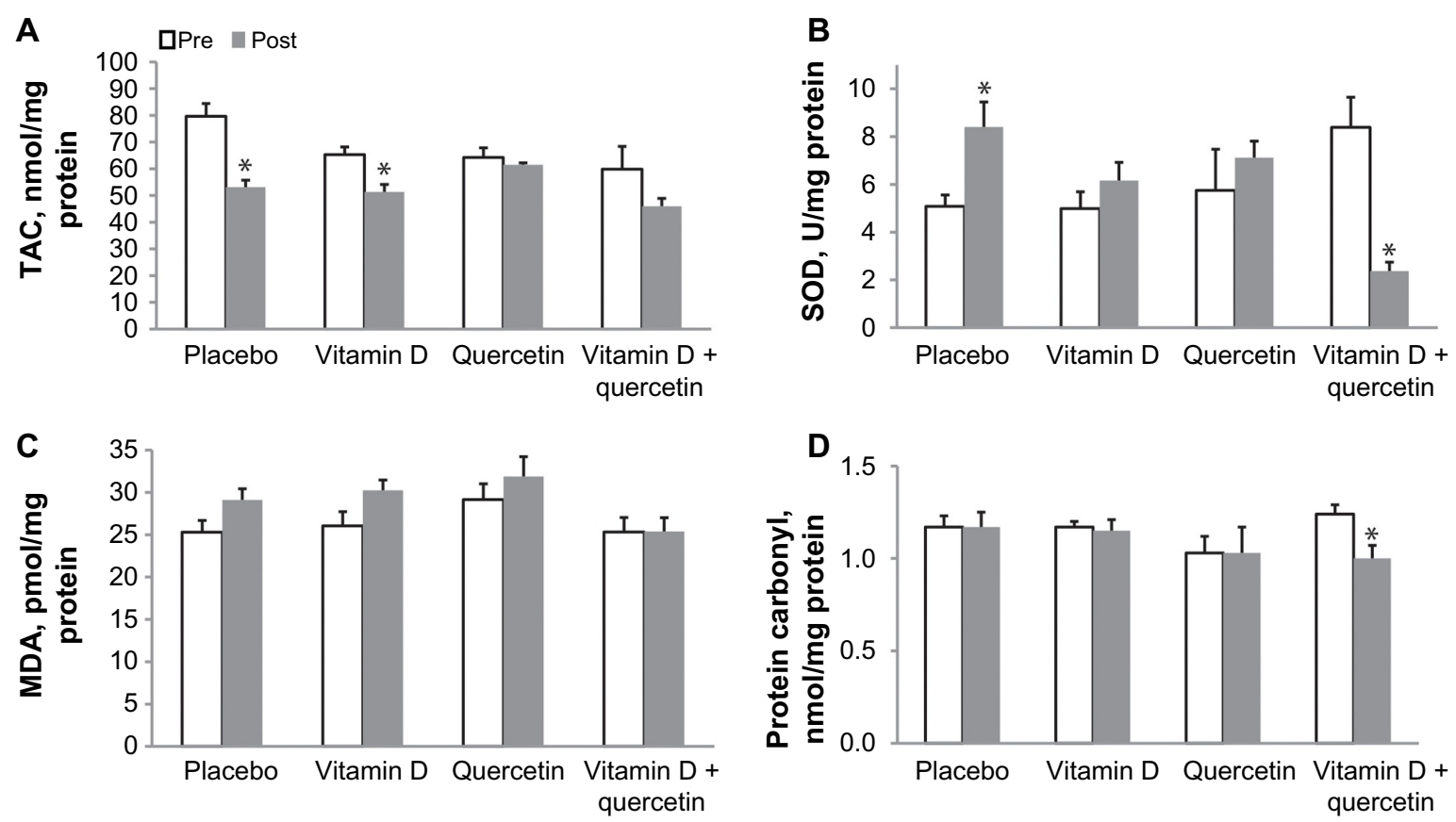

Figure 3 Markers of antioxidant status in serum.

Notes: $(\mathbf{A})$ TAC values were decreased from pre- to postsupplementation in the placebo $(P<0.00 \mathrm{I})$, vitamin $D_{3}(P=0.002)$, and $D+Q(P=0.155)$ groups. (B) SOD activity was significantly increased in the placebo group $(P=0.009)$ and significantly decreased in the $D+Q$ group $(P<0.00 I)$ group, possibly implying a protective antioxidant effect of the combined supplementation. (C) No significant changes in MDA levels (lipid peroxidation) were found. (D) A significant decrease in the protein carbonyl level (protein oxidation) was found for the $D+Q(P=0.023)$ group, possibly implying a protective antioxidant effect of the combined supplementation. Values are mean \pm SEM. The asterisk indicates significant difference from pre- to postsupplementation $(P<0.05)$.

Abbreviations: TAC, total antioxidant capacity; SOD, superoxide dismutase; D + Q, vitamin D + quercetin; MDA, malondialdehyde; SEM, standard error of mean.

any improvement in muscular strength of vitamin D sufficient $(>50 \mathrm{nmol} / \mathrm{L})$ healthy adult males. These differences may be due to a young age and a sufficient baseline serum $25(\mathrm{OH}) \mathrm{D}$ levels ( $>50 \mathrm{nmol} / \mathrm{L})$ of participants in our study.

Quercetin supplementation has been associated with improved cardiorespiratory fitness, possibly through its role as an antioxidant. Davis et $\mathrm{al}^{70}$ reported significant improvements in time to fatigue and $\mathrm{VO}_{2 \max }$ in nonathletic individuals supplemented with $500 \mathrm{mg} / \mathrm{d}$ of quercetin for 7 days, indicating the potential importance of quercetin for enhancing aerobic performance. We previously reported that supplementation of trained participants with $1,000 \mathrm{mg} / \mathrm{d}$ of quercetin for 6 weeks tends to increase $\mathrm{VO}_{2 \text { max }}$, suggesting a slight improvement in cardiorespiratory fitness through reducing oxidative stress. ${ }^{18}$

In this study, quercetin and vitamin D supplementation did produce significant changes in antioxidant status. However, these biomarker changes were not in parallel with one another limiting the strength of these findings. ${ }^{71}$ Furthermore, these changes were not significant enough to enhance physical performance $\left(\mathrm{VO}_{2 \max }, 5 \mathrm{~km} \mathrm{TT}\right.$, or LT), possibly due to the high initial antioxidant status of the participants. These null findings in trained participants are similar to two other studies that reported no effects on several measures of oxidative stress and antioxidant capacity with quercetin supplementation for 6-12 weeks. $^{72,73}$

An association between vitamin D staus and cardiorespiratory fitness $\left(\mathrm{VO}_{2 \max }\right)$ in healthy adults has been reported. ${ }^{19,21}$ The current investigation assessed the effect of vitamin $D_{3}$ supplementation on outcomes of cardiorespiratory fitness, but did not find a significant increase in $\mathrm{VO}_{2 \max }, 5 \mathrm{~km}$ TT, or LT with a significant increase in vitamin D status. The participants in this study were young, physically fit, vitamin D sufficient males, with a body mass index of 25.3 and $\mathrm{VO}_{2 \max }$ of $51.8 \mathrm{~mL} /(\mathrm{kg} \cdot \mathrm{min})$. These factors could limit the potential beneficial effects of vitamin $\mathrm{D}$ supplementation. It is possible that a higher $(>4,000 \mathrm{IU} / \mathrm{d})$ intake of vitamin $\mathrm{D}_{3}$ further increases $25(\mathrm{OH}) \mathrm{D}$ concentration and could result in an improved physical performance, as found in two studies using athletic populations. ${ }^{60,74,75}$ However, it was not possible for us to supplement with $>4,000 \mathrm{IU} / \mathrm{d}$, as we were restricted by the Institutional Review Board from exceeding the Upper Limit set by the Institute of Medicine due to concerns of toxicity. Finally, previous evidence suggests quercetin supplementation has a small effect size for improving performance. Our study may have been underpowered to find such an effect. However, the addition of vitamin D should probably have strengthened this effect. 
It would have been interesting to have utilized an athletic team which would have the advantages of a similar training plan, performance status, age, and meal plan for all subjects. Additionally, future approaches could incorporate greater bouts of intensity to elicit a greater amount of oxidative stress, recruitment of vitamin $\mathrm{D}$ deficient $(<30 \mathrm{nmol} / \mathrm{L})$ subjects incorporating an adequate repletion regiment, and increased supplementation amounts of quercetin or vitamin D with or without other flavonoids. Finally, a study designed to improve measures of fitness would investigate the added training effects of supplementation with quercetin or vitamin $\mathrm{D}$.

\section{Conclusion}

The results obtained demonstrated that vitamin $\mathrm{D}_{3}$ supplementation at a tolerable UL (4,000 IU/d) for 8 weeks significantly increases vitamin D status (serum 25(OH) D concentration). However, vitamin $\mathrm{D}_{3}$ alone, quercetin alone, and their combination did not produce significant changes in the markers associated with antioxidant status or the steroid hormone regulators of muscle function and did not influence physical performance outcomes in physically active males. These findings indicate that long-term vitamin D and quercetin supplementation do not improve physical performance in male adults with adequate vitamin $\mathrm{D}$, testosterone, and antioxidant status and do not support the supplementation with vitamin D and quercetin, singularly or in combination, for enhancing physical performance in physically active male adults.

\section{Acknowledgments}

The authors thank Kirsten Townley and Emily Johnson for help with data collection. This work was supported by an Institutional Development Award (IDeA) from the National Institute of General Medical Sciences of the National Institutes of Health under grant number P20GM103443. Its contents are solely the responsibility of the authors and do not necessarily represent official views of NIGMS or NIH. This work was also supported in part by the US Department of agriculture grants SD00H325 and SD00H533.

\section{Author contributions}

The sequence of authors reflects their relative contributions. Conceived and designed the study: SDS and INS; acquired and interpreted the data: all authors; carried out biomarkers assays: QS; performed statistical analysis: CBB; wrote manuscript: SDS and INS; critical revision and approval of the final version of the manuscript: all authors.

\section{Disclosure}

The authors report no conflicts of interest in this work.

\section{References}

1. Wiens K, Erdman KA, Stadnyk M, Parnell JA. Dietary supplement usage, motivation, and education in young, canadian athletes. Int $J$ Sport Nutr Exerc Metab. 2014;24(6):613-622.

2. Salgado JV, Lollo PC, Amaya-Farfan J, Chacon-Mikahil MP. Dietary supplement usage and motivation in Brazilian road runners. J Int Soc Sports Nutr. 2014;11:41.

3. Askari G, Ghiasvand R, Karimian J, et al. Does quercetin and vitamin C improve exercise performance, muscle damage, and body composition in male athletes? J Res Med Sci. 2012;17(4):328-331.

4. MacRae HS, Mefferd KM. Dietary antioxidant supplementation combined with quercetin improves cycling time trial performance. Int $J$ Sport Nutr Exerc Metab. 2006;16(4):405-419.

5. Tobias G, Benatti FB, de Salles Painelli V, et al. Additive effects of beta-alanine and sodium bicarbonate on upper-body intermittent performance. Amino Acids. 2013;45(2):309-317.

6. Burke LM, Read RS. Dietary supplements in sport. Sports Med. 1993; 15(1):43-65.

7. Larson-Meyer DE, Burke LM, Stear SJ, Castell LM. A-Z of nutritional supplements: dietary supplements, sports nutrition foods and ergogenic aids for health and performance: Part 40. Br J Sports Med. 2013;47(2): 118-120.

8. Reid MB. Free radicals and muscle fatigue: Of ROS, canaries, and the IOC. Free Radical Biol Med. 2008;44(2):169-179.

9. Bentley DJ, Dank S, Coupland R, Midgley A, Spence I. Acute antioxidant supplementation improves endurance performance in trained athletes. Res Sports Med. 2012;20(1):1-12.

10. Aguilo A, Tauler P, Sureda A, Cases N, Tur J, Pons A. Antioxidant diet supplementation enhances aerobic performance in amateur sportsmen. J Sports Sci. 2007;25(11):1203-1210.

11. Slattery KM, Dascombe B, Wallace LK, Bentley DJ, Coutts AJ. Effect of $\mathrm{N}$-acetylcysteine on cycling performance after intensified training. Med Sci Sports Exerc. 2014;46(6):1114-1123.

12. Zhang M, Swarts SG, Yin L, et al. Antioxidant properties of quercetin. Adv Exp Med Biol. 2011;701:283-289.

13. McAnulty LS, Miller LE, Hosick PA, Utter AC, Quindry JC, McAnulty SR. Effect of resveratrol and quercetin supplementation on redox status and inflammation after exercise. Appl Physiol Nutr Metab. 2013;38(7): 760-765.

14. Gao C, Chen X, Li J, et al. Myocardial mitochondrial oxidative stress and dysfunction in intense exercise: regulatory effects of quercetin. Eur J Appl Physiol. 2014;114(4):695-705.

15. Davis JM, Murphy EA, Carmichael MD. Effects of the dietary flavonoid quercetin upon performance and health. Curr Sports Med Rep. 2009;8(4):206-213.

16. Nieman DC, Henson DA, Davis JM, et al. Quercetin's influence on exercise-induced changes in plasma cytokines and muscle and leukocyte cytokine mRNA. J Appl Physiol. 2007;103(5):1728-1735.

17. Cureton KJ, Tomporowski PD, Singhal A, et al. Dietary quercetin supplementation is not ergogenic in untrained men. JAppl Physiol. 2009;107(4): 1095-1104.

18. Scholten SD, Sergeev IN. Long-term quercetin supplementation reduces lipid peroxidation but does not improve performance in endurance runners. Open Access J Sports Med. 2013;4:53-61.

19. Ardestani A, Parker B, Mathur S, et al. Relation of vitamin D level to maximal oxygen uptake in adults. Am J Cardiol. 2011;107(8):1246-1249.

20. Mowry DA, Costello MM, Heelan KA. Association among cardiorespiratory fitness, body fat, and bone marker measurements in healthy young females. J Am Osteopath Assoc. 2009;109(10):534-539.

21. Farrell SW, Cleaver JP, Willis BL. Cardiorespiratory fitness, adiposity, and serum 25-dihydroxyvitamin D levels in men. Med Sci Sports Exerc. 2011;43(2):266-271. 
22. Farrell SW, Willis BL. Cardiorespiratory fitness, adiposity, and serum 25-dihydroxyvitamin D levels in women: the Cooper Center Longitudinal Study. J Womens Health. 2012;21(1):80-86.

23. Powers $\mathrm{S}$, Nelson WB, Larson-Meyer E. Antioxidant and vitamin D supplements for athletes: sense or nonsense? J Sports Sci.2011;29(Supp1 1): S47-S55.

24. Larson-Meyer DE, Willis KS. Vitamin D and athletes. Curr Sports Med Rep. 2010;9(4):220-226.

25. Larson-Meyer E. Vitamin D supplementation in athletes. Nestle Nutr Inst Workshop Ser. 2013;75:109-121.

26. Christakos S, Hewison M, Gardner DG, et al. Vitamin D: beyond bone. Ann NY Acad Sci. 2013;1287:45-58.

27. Constantini NW, Arieli R, Chodick G, Dubnov-Raz G. High prevalence of vitamin D insufficiency in athletes and dancers. Clin J Sports Med. 2010;20(5):368-371.

28. Galan F, Ribas J, Sanchez-Martinez PM, Calero T, Sanchez AB, Munoz A. Serum 25-hydroxyvitamin D in early autumn to ensure vitamin D sufficiency in mid-winter in professional football players. Clin Nutr. 2012;31(1):132-136.

29. Hamilton B, Grantham J, Racinais S, Chalabi H. Vitamin D deficiency is endemic in Middle Eastern sportsmen. Public Health Nutr. 2010;13(10): $1528-1534$.

30. Angeline ME, Gee AO, Shindle M, Warren RF, Rodeo SA. The effects of vitamin D deficiency in athletes. Am J Sports Med. 2013;41(2): 461-464.

31. Norman AW, Nemere I, Zhou LX, et al. $1,25(\mathrm{OH})_{2}$-vitamin $\mathrm{D}_{3}$, a steroid hormone that produces biologic effects via both genomic and nongenomic pathways. J Steroid Biochem Mol Biol. 1992;41(3-8): 231-240.

32. Spirichev VB, Sergeev IN. Vitamin D: experimental research and its practical application. World Rev Nutr Diet. 1988;56:173-216.

33. Sergeev IN, Rhoten WB, Spirichev VB. Vitamin D and intracellular calcium. Subcell Biochem. 1998;30:271-297.

34. Sergeev IN. Vitamin D and cellular $\mathrm{Ca}^{2+}$ signaling in breast cancer. Anticancer Res. 2012;32(1):299-302.

35. Pilz S, Frisch S, Koertke H, et al. Effect of vitamin D supplementation on testosterone levels in men. Horm Metab Res. 2011;43(3):223-225.

36. Nimptsch K, Platz EA, Willett WC, Giovannucci E. Association between plasma 25-OH vitamin D and testosterone levels in men. Clin Endocrinol. 2012;77(1):106-112.

37. Mauras N, Hayes V, Welch S, et al. Testosterone deficiency in young men: marked alterations in whole body protein kinetics, strength, and adiposity. J Clin Endocrinol Metab. 1998;83(6):1886-1892.

38. Song Q, Sergeev IN. Calcium and vitamin D in obesity. Nutr Res Rev. 2012;25(1):130-141.

39. Sergeev I. Regulation of apoptosis in adipocytes and breast cancer cells by $1,25(\mathrm{OH})_{2}$-vitamin $\mathrm{D}_{3}$ : a link between metabolic disorders and breast cancer. Horm Mol Biol Clin Investig. 2013;14:99-106.

40. Sergeev IN, Rhoten WB. 1,25-Dihydroxyvitamin $\mathrm{D}_{3}$ evokes oscillations of intracellular calcium in a pancreatic beta-cell line. Endocrinology. 1995;136(7):2852-2861.

41. Sergeev IN, Song Q. High vitamin D and calcium intakes reduce dietinduced obesity in mice by increasing adipose tissue apoptosis. Mol Nutr Food Res. 2014:1342-1348.

42. Bartoszewska M, Kamboj M, Patel DR. Vitamin D, muscle function, and exercise performance. Pediatr Clin North Am. 2010;57(3): 849-861.

43. Dhesi JK, Jackson SH, Bearne LM, et al. Vitamin D supplementation improves neuromuscular function in older people who fall. Age Ageing. 2004;33(6):589-595.

44. Ceglia L. Vitamin D and its role in skeletal muscle. Curr Opin Clin Nutr Metab Care. 2009;12(6):628-633.

45. Sergeev IN. Vitamin D-mediated apoptosis in cancer and obesity. Horm Mol Biol Clin Investig. 2014;20(2):43-49.

46. Muir SW, Montero-Odasso M. Effect of vitamin D supplementation on muscle strength, gait and balance in older adults: a systematic review and meta-analysis. J Am Geriatr Soc. 2011;59(12):2291-2300.
47. Stockton KA, Mengersen K, Paratz JD, Kandiah D, Bennell KL. Effect of vitamin D supplementation on muscle strength: a systematic review and meta-analysis. Osteoporosis Int. 2011;22(3):859-871.

48. Annweiler C, Schott AM, Berrut G, Fantino B, Beauchet O. Vitamin D related changes in physical performance: a systematic review. J Aging Health. 2009;13(10):893-898.

49. Latham NK, Anderson CS, Lee A, Bennett DA, Moseley A, Cameron ID. A randomized, controlled trial of quadriceps resistance exercise and vitamin D in frail older people: the Frailty Interventions Trial in Elderly Subjects (FITNESS). J Am Geriatr Soc. 2003;51(3):291-299.

50. Dogan M, Cesur Y, Zehra Dogan S, Kaba S, Bulan K, Cemek M. Oxidant/ antioxidant system markers and trace element levels in children with nutritional rickets. J Pediatr Endocrinol Metab. 2012;25(11-12): 1129-1139.

51. Mellenthin L, Wallaschofski H, Grotevendt A, Volzke H, Nauck M, Hannemann A. Association between serum vitamin D concentrations and inflammatory markers in the general adult population. Metabolism. 2014;63(8):1056-1062.

52. Willis KS, Smith DT, Broughton KS, Larson-Meyer DE. Vitamin D status and biomarkers of inflammation in runners. Open Access $J$ Sports Med. 2012;3:35-42.

53. Ross AC, Manson JE, Abrams SA, et al. The 2011 report on dietary reference intakes for calcium and vitamin $D$ from the Institute of Medicine: what clinicians need to know. J Clin Endocrinol Metab. 2011;96(1):53-58.

54. Bergeron MF, Laird MD, Marinik EL, Brenner JS, Waller JL. Repeated-bout exercise in the heat in young athletes: physiological strain and perceptual responses. J Appl Physiol. 2009;106(2):476-485.

55. Bentley DJ, Newell J, Bishop D. Incremental exercise test design and analysis: implications for performance diagnostics in endurance athletes. Sports Med. 2007;37(7):575-586.

56. Pincivero DM, Gandaio CM, Ito Y. Gender-specific knee extensor torque, flexor torque, and muscle fatigue responses during maximal effort contractions. Eur J Appl Physiol. 2003;89(2):134-141.

57. Bloomer RJ. Effect of exercise on oxidative stress biomarkers. $A d v$ Clin Chem. 2008;46:1-50.

58. Ross AC TC, Yaktine AL, Del Valle HB. Institute of Medicine (US) Committee to Review Dietary Reference Intakes for Vitamin D and Calcium. Washington, DC: National Academies Press; 2011.

59. Holick MF, Binkley NC, Bischoff-Ferrari HA, et al. Evaluation, treatment, and prevention of vitamin D deficiency: an endocrine society clinical practice guideline. J Clin Endocrinol Metab. 2011;96(7):1911-1930.

60. Close GL, Leckey J, Patterson M, et al. The effects of vitamin $\mathrm{D}_{3}$ supplementation on serum total $25(\mathrm{OH}) \mathrm{D}$ concentration and physical performance: a randomised dose-response study. $\mathrm{Br} J$ Sports Med. 2013;47(11):692-696.

61. Close GL, Russell J, Cobley JN, et al. Assessment of vitamin D concentration in non-supplemented professional athletes and healthy adults during the winter months in the UK: implications for skeletal muscle function. J Sports Sci. 2012;22:1-10.

62. Vieth R. Vitamin D supplementation, 25-hydroxyvitamin D concentrations, and safety. Am J Clin Nutr. 1999;69(5):842-856.

63. Bischoff-Ferrari HA, Giovannucci E, Willett WC, Dietrich T, Dawson-Hughes B. Estimation of optimal serum concentrations of 25-hydroxyvitamin D for multiple health outcomes. Am J Clin Nutr. 2006;84(1):18-28.

64. van Groningen L, Opdenoordt S, van Sorge A, Telting D, Giesen A, de Boer $\mathrm{H}$. Cholecalciferol loading dose guideline for vitamin D-deficient adults. Eur J Endocrinol. 2010;162(4):805-811.

65. Wehr E, Pilz S, Boehm BO, Marz W, Obermayer-Pietsch B. Association of vitamin D status with serum androgen levels in men. Clin Endocrinol. 2010;73(2):243-248.

66. Jorde R, Grimnes G, Hutchinson MS, Kjaergaard M, Kamycheva E, Svartberg J. Supplementation with vitamin D does not increase serum testosterone levels in healthy males. Horm Metab Res. 2013;17:17.

67. Kenny AM, Prestwood KM, Gruman CA, Marcello KM, Raisz LG. Effects of transdermal testosterone on bone and muscle in older men with low bioavailable testosterone levels. J Gerontol A Biol Sci Med Sci. 2001;56(5):M266-M272. 
68. Yeap BB, Almeida OP, Hyde Z, et al. Healthier lifestyle predicts higher circulating testosterone in older men: the Health In Men Study. Clin Endocrinol. 2009;70(3):455-463.

69. Sato Y, Iwamoto J, Kanoko T, Satoh K. Low-dose vitamin D prevents muscular atrophy and reduces falls and hip fractures in women after stroke: a randomized controlled trial. Cerebrovasc Dis. 2005;20(3):187-192.

70. Davis JM, Carlstedt CJ, Chen S, Carmichael MD, Murphy EA. The dietary flavonoid quercetin increases $\mathrm{VO}_{2 \max }$ and endurance capacity. Int J Sport Nutr Exerc Metab. 2010;20(1):56-62.

71. Powers SK, Smuder AJ, Kavazis AN, Hudson MB. Experimental guidelines for studies designed to investigate the impact of antioxidant supplementation on exercise performance. Int J Sport Nutr Exerc Metab. 2010;20(1):2-14.
72. Shanely RA, Knab AM, Nieman DC, Jin FX, McAnulty SR, Landram MJ. Quercetin supplementation does not alter antioxidant status in humans. Free Radic Res. 2010;44(2):224-231.

73. McAnulty SR, McAnulty LS, Nieman DC, et al. Chronic quercetin ingestion and exercise-induced oxidative damage and inflammation. Appl Physiol Nutr Metab. 2008;33(2):254-262.

74. Gupta R, Sharma U, Gupta N, et al. Effect of cholecalciferol and calcium supplementation on muscle strength and energy metabolism in vitamin D-deficient Asian Indians: a randomized, controlled trial. Clin Endocrinol. 2010;73(4):445-451.

75. Hodgson A, Ingham A, Martin J, Roberts T, Jeukendrup AE. The effects of 4 weeks vitamin $\mathrm{D}_{3}$ supplementation on athletic performance. ACSM 59th Ann Meeting Abstr. 2012;44(5):S721.

\section{Publish your work in this journal}

Open Access Journal of Sports Medicine is an international, peer-reviewed, open access journal publishing original research, reports, reviews and commentaries on all areas of sports medicine. The manuscript management system is completely online and includes a very quick and fair peer-review system.
Visit http://www.dovepress.com/testimonials.php to read real quotes from published authors. 